\title{
Physical Dimensions And Tar And Nicotine Yields of Fine-cut Smoking Articles Rolled by German Consumers
}

\author{
Hary F. Dymond \\ 45, Monarch Way, West End, \\ Southampton, SO30 3JQ \\ United Kingdom.
}

\section{SUMMARY}

In 1994, the European Smoking Tobacco Association (ESTA) commissioned and reported a study undertaken in the Netherlands to determine the making habits of roll-your-own smokers. The study included laboratory smoking of the collected smoking articles for the determination of tar and nicotine. In 1997, ESTA commissioned a similar study for Germany involving German fine-cut smokers. This paper reviews the data produced from the German study and compares the data with that produced in the Netherlands. An independent market research agency recruited known smokers of fine-cut tobacco. They were given the most popular brand of tobacco and the most popular brand of booklet paper. The consumers were instructed to make a fine-cut smoking article for testing each time they wanted to smoke. These smoking articles were placed in protective tins and collected by the research agency for analysis. An independent laboratory in Germany undertook the smoking and analysis. This study shows that a German roll-your-own smoker uses an average of $830 \mathrm{mg}$ tobacco and makes a product that is 7.6 $\mathrm{mm}$ in diameter. German booklet paper is slightly shorter than Dutch paper. German products are more cylindrical than Dutch products and this probably accounts for the much reduced variability of German products compared with Dutch products. The mean tar yield of these articles was $12 \mathrm{mg}$ and the mean nicotine yield was $0.9 \mathrm{mg}$. [Beitr. Tabakforsch. Int. 18 (1999) 165-174]

\section{ZUSAMMENFASSUNG}

Der europäische Rauchtabakverband ESTA [European Smoking Tobacco Association] ließ 1994 in den Niederlanden eine Studie über die Anfertigung selbstgedrehter Rauchartikel durchführen und die Ergebnisse auswerten. Die im Rahmen dieser Studie gesammelten Rauchartikel wurden im Labor abgeraucht und die Kondensat- und Nikotinwerte bestimmt. 1997 gab die ESTA eine ähnliche Studie für Deutschland in Auftrag, in der das Verhalten deutscher Feinschnittraucher untersucht wurde. Die hier vorliegende Arbeit berichtet über die Daten der deutschen Studie und vergleicht die Ergebnisse mit denen der niederländischen Studie. Ein unabhängiges Marktforschungsinstitut rekrutierte Feinschnittkonsumenten, denen die bekannteste Feinschnitttabaksorte und das bekannteste Cigarettenpapier gegeben wurde. Die Raucher wurden angewiesen, jedes Mal, wenn sie rauchen wollten, einen selbstgedrehten Rauchartikel für Testzwecke anzufertigen. Diese wurden in Schutzbehältnissen aufbewahrt und vom Marktforschungsinstitut zu Analysezwecken gesammelt. Ein unabhängiges Labor in Deutschland führte das Abrauchen und die Analyse der selbstgedrehten Rauchartikel durch. Die Ergebnisse dieser Studie zeigten, dass ein deutscher Raucher selbstgedrehter Rauchartikel durchschnittlich $830 \mathrm{mg}$ Tabak verwendet und ein Produkt mit einem Durchmesser von $7.6 \mathrm{~mm}$ herstellt. Deutsches Cigarettenpapier ist geringfügig kürzer als niederländisches. Selbstgedrehte Rauchartikel sind in Deutschland zylinderförmiger als in den Niederlanden, was sicherlich die geringere Variabilität deutscher Produkte im Vergleich zu niederländischen Produkten 
erklärt. Die durchschnittlichen Kondensatwerte dieser Rauchartikel lagen bei $12 \mathrm{mg}$ und die durchschnittlichen Nikotinwerte bei $0.9 \mathrm{mg}$. [Beitr. Tabakforsch. Int. 18 (1999) 165-174]

\section{RESUME}

En 1994, l'association européenne de tabacs de coupe fine, ESTA [European Smoking Tobacco Association], a réalisé une étude aux Pays-Bas sur les habitudes de confection de cigarettes par les consommateurs du tabac à rouler RYO [roll-your-own]. Dans cette étude les produits confectionnés ont été fumés par une machine à fumer pour déterminer les rendements en goudron et nicotine. En 1997, l'ESTA a commissionné une étude analogue pour l'Allemagne avec des consommateurs allemand du tabac RYO. Cet article examine les résultats obtenus par l'étude allemande et les compare avec les résultats obtenus par l'étude hollandaise. Un institut indépendant d'étude de marché a choisi des fumeurs consommateur du tabac à rouler. On leur avait procuré le tabac et le papier les plus connus. Les consommateurs ont réalisé des produits à fumer pour usages analytiques chaque fois qu'ils voulaient fumer. Ces produits confectionnés ont été placés dans des récipients par l'institut d'analyse. Un laboratoire indépendant en Allemagne a effectué le fumage et les analyses. Les résultats montrent qu'un consommateur allemand d' articles RYO utilise en moyenne $830 \mathrm{mg}$ de tabacs et confectionne un article à fumer d'un diamètre moyen de 7.6 $\mathrm{mm}$. Le papier allemand est légèrement plus petit que le papier hollandais. Les articles allemands ont une forme plus conique que les articles hollandais et ceci mène probablement au fait que les produits allemands sont moins hétérogènes comparés aux produits hollandais. Le rendement moyen en goudron est de $12 \mathrm{mg}$ et de $0.9 \mathrm{mg}$ en nicotine. [Beitr. Tabakforsch. Int. 18 (1999) 165-174]

\section{INTRODUCTION}

In 1996, a similar paper to the present one was published by H.F. DYMOND entitled "Making habits of roll-your-own smokers in the Netherlands and tar and nicotine yields from the resultant products" (1). In that paper it was pointed out that fine-cut tobacco cannot be used without the intervention of the consumer who has the choice to use different papers with different properties and in some cases to use filters. It is the make-up of the smoking article that the consumer produces and not just the tobacco used which determines the yields. The paper published in 1996, was a comprehensive study of articles collected from the Dutch market and subsequently smoked to determine the nicotine-free dry particulate matter
(NFDPM) and nicotine yields. Considering the total volume of tobacco used, the German market is the second-largest market after the Netherlands. Latest available total consumption figures suggest that some 11,600 tonnes of fine-cut tobacco is used per annum in Germany. The object of the present study was to investigate further how consumers roll smoking articles from fine-cut tobacco in Germany, to determine the tar and nicotine yields obtained when these consumer-made articles are smoked and to compare the physical data and tar/nicotine yield data with the values obtained from the study reported in 1996 in Holland.

\section{MATERIALS AND METHODS}

This study was commissioned by the European Smoking Tobacco Association which represents the leading manufacturers of fine-cut tobacco in Europe. The study was conducted in Germany by an independent market research agency (EMNID-Institut $\mathrm{GmbH}$ in Bielefeld, Germany). The laboratory determinations were conducted by an independent laboratory in Germany (Untersuchungs- u. Forschungslabor Umwelt $\mathrm{GmbH}$ - [UFU] in Herbrechtingen, Germany).

\section{Study design}

The study consisted of four stages. A selection of a representative sample of roll-your-own smokers; consumer making of fine-cut smoking articles; laboratory analysis of fine-cut smoking articles; and statistical analysis of the consumer and laboratory data.

Stage 1 - Consumer selection

EMNID-Institut GmbH recruited a panel of consumers. They were recruited by telephone on the basis of a selection questionnaire. 146 respondents were originally selected and represented the original sample size. However, 10 respondents did not follow the instructions and returned articles using loose filters. The products from these 10 respondents were disregarded. In addition, one further respondent was disregarded as only 10 rolled articles were returned. This left a final sample size of 135 respondents. As part of the selection criteria it was established that the respondents were aged 18 or over, regularly make hand-rolled cigarettes, smoke at least on one or two days per week and are smokers of the brand of tobacco being investigated. 
Each respondent was issued with 3 packs of DRUM Halfzware Tobacco, 3 packets of Gizeh Gelb paper, a tin and a set of instructions plus a questionnaire. DRUM Halfzware and Gizeh Gelb are the leading brands of tobacco and roll-your-own paper in the German market.

The Gizeh Gelb booklet paper used in this study is a $100 \%$ woodpulp paper with a nominal porosity of 40 CU (CORESTA unit) $\left(\mathrm{cm}^{3} \times \mathrm{min}^{-1}\right) / \mathrm{cm}^{2}$ when measured at $1 \mathrm{kPa}$ and determined by CORESTA Recommended Method No. 40. It is impregnated with $1.3 \% 1: 1$ mixture of sodium and potassium citrate. The length is $68 \mathrm{~mm}$ and the width is 35.8 $\mathrm{mm}$.

Respondents were asked to make 22 hand-rolled articles for test purposes. They were asked to make these articles when they would normally make one to smoke but instead of smoking it to place the newly made article into the tin provided, marking the mouth end. The market research institute then collected all the tins and sent them to the analytical laboratory.

\section{Stage $3 \rightarrow$ Laboratory analysis}

All tins containing smoking articles were sent to the Untersuchungs- u. Forschungslabor Umwelt $\mathrm{GmbH}$ [UFU]. Only those from the 135 respondents who filled the criteria of the questionnaire of the study were examined. On arrival at the laboratory, one smoking article was taken at random from each of the tins and tested for moisture content by the Karl Fischer water determination method (2). This was done to determine whether the samples had been correctly treated by the respondents and that they were received in reasonable condition and had not dried out. The remaining 21 articles were then conditioned for at least 3 days at $22{ }^{\circ} \mathrm{C}$ and $75 \%$ relative humidity $(\mathrm{RH})$. After conditioning, the moisture content of another article from each tin was determined using the Karl Fischer method. The mean result was $19.5 \%$ with a standard deviation of $0.9 \%$. As in the Dutch study the remaining articles were then measured for gross weight including the paper (net weight was calculated by subtracting the nominal weight of the paper) and the diameter at three places.

The articles were again conditioned at $75 \% \mathrm{RH}$ and $22{ }^{\circ} \mathrm{C}$. They were then and afterwards smoked using a Borgwaldt rotary smoking machine (Heinrich Borgwaldt Hamburg, Germany) conforming to the specification given in ISO 3308 (3).

Smoking was performed in a laboratory conditioned at $22{ }^{\circ} \mathrm{C}$ and $60 \% \mathrm{RH}$. Individual $44 \mathrm{~mm}$ glass fibre filter holders conforming to ISO 3308 were used to collect the smoke from each article, so that yields of individual smoking articles could be determined. The cigarette holder described in ISO 3308 and ISO 4387 (4) was considered unsuitable for fine-cut smoking articles because of a tendency for leakage around the soft, non-cylindrical ends of consumer-made, handrolled, smoking articles. At the time of this work, the holder, known as the sleeve holder, designed by Filtrona Instruments and Automation Ltd. specifically for the holding of fine-cut smoking articles, was not available. Consequently, the holder described in ISO 3308 and ISO 4387 was modified to allow a greater insertion depth to be used to reduce leakage on the article. A longer cap with six labyrinth seals was used. This resulted in an insertion depth of 13 $\mathrm{mm}$ which is longer than the insertion depth of $9 \mathrm{~mm}$ specified in ISO 4387. As a result of the longer insertion depth and the variable burning rate of the articles, it was necessary to smoke to a $27 \mathrm{~mm}$ butt length.

Measurements were made of particulate matter, water, and nicotine yields, and from these, nicotinefree dry particulate matter (NFDPM, i.e. tar) was calculated. A total of 2700 smoke yield sets was obtained.

\section{Stage 4 - Statistical evaluation}

The laboratory data were sent to EMNID-Institut $\mathrm{GmbH}$ for evaluation. An initial examination of the data indicated a number of obvious errors which were due to transcription and technical problems mentioned by the laboratory, as well as statistical outliers.

For each variable determined from the remaining 135 respondents, extreme values were traced and inspected to ensure that they did not represent dataentry errors. The extreme values for a particular variable were evaluated against the remarks made by the laboratory to see if they could be explained. In the first instance, extreme values were detected using statistical 'stem-leaf' plots for each variable. The original data entry was checked and then the data evaluated in order to judge whether the extreme values were likely. The measured values of four respondents represented a technically improbable combination of the measured variables and were removed from the data set.

In addition, another 45 fine-cut smoking articles lacked a measured variable, had a suspicious value for one of the variables, had a technical defect reported by the laboratory or had an illogical NFDPM/nicotine ratio. These individual data points were also removed.

This left valid data sets from 131 respondents and a total of 2575 individual data sets for analysis. 


\section{RESULTS AND DISCUSSION}

This study was executed in exactly the same way as the Dutch study. Overall the results of both studies are consistent with each other.

The moisture content of the smoking articles was $19 \%$ based on the laboratory analysis. This is the intended moisture content at which fine-cut tobacco is sold, rolled, and smoked by the German consumer. Interestingly, the value is slightly higher than that determined in the Dutch study where it was $17 \%$.

The results for consumer-made smoking articles made from DRUM Halfzware tobacco and Gizeh Gelb paper in Germany are given in Table 1. Calculations were made of mean, standard deviation, minimum, maximum, and median. The distribution of all parameters was depicted by using histograms. Values were calculated at the individual smoking article level and at the mean respondent level. These are shown as Figures $1 \mathrm{a}$ and $1 \mathrm{~b}$ to $4 \mathrm{a}$ and $4 \mathrm{~b}$ depicting the distribution of weight, diameter, tar yield, and yield of nicotine in smoke.

In addition to the measured data, various values were computed. This included a calculation to demonstrate the shape of the smoking article. Values were calculated for the diameter at the lit end minus the diameter of the middle and also the difference in diameter between the middle and the mouth end. A plot showing the distribution of shape is shown as Figure 5. This is compared with the distribution of shape for the Dutch products shown in Figure 6. It can be seen that the German distribution is much more symmetrical around the origin than the Dutch. This indicates that German consumers exhibit a slight tendency to produce a conical product but to a much lesser extent than Dutch consumers.

\section{Table 1.}

Data from consumer-made smoking articles handrolled in Germany (using DRUM Halfzware tobacco and Gizeh Gelb paper) (based at the respondent level).

\begin{tabular}{lcc}
\hline Variable & Mean & $\begin{array}{c}\text { Standard } \\
\text { Deviation }\end{array}$ \\
\hline Tobacco weight $(\mathrm{mg})$ & 830 & 178 \\
Mean diameter $(\mathrm{mm})$ & 7.6 & 0.8 \\
NFDPM $^{\mathrm{a}}(\mathrm{mg})$ & 12.1 & 2.5 \\
Nicotine in smoke $(\mathrm{mg})$ & 0.94 & 0.18 \\
\hline
\end{tabular}

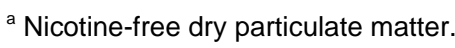

The data support the earlier consumer studies in terms of typical weight and average diameter. Data from these studies was given in the paper "Making habits of roll-your-own smokers in the Netherlands and tar and nicotine yields from the resultant products", Tobacco Science 40 (1996) 87-91 (1).

Comparing the data given in this paper with that reported from the Dutch study, it can be seen that the standard deviation of the tobacco weight and diameter from the German consumers are greater than those from the Dutch consumers. A study of the histograms shows that the distribution of tobacco weight is influenced by a few consumers who make particularly heavy or light articles and hence affect the standard deviation. This is easily seen in the difference between the minimum and maximum values. This making behaviour is also reflected in the mean diameter.

German smokers make articles that yield slightly less NFDPM and nicotine than Dutch consumers. The standard deviation of both NFDPM and nicotine of the German articles are significantly lower than the Dutch. Looking at the histograms it can be seen that there is a very broad distribution amongst the Dutch consumers. It is likely that this is an artefact of the making behaviour and that conical products produce more variable yields than the more symmetrical German products.

DARRALL and FIGGINS (5) recently reported on a study conducted in the United Kingdom. In this study 26 consumers were asked to make 20 fine-cut smoking articles at one time. The products were stored at $22{ }^{\circ} \mathrm{C}$ and $75 \% \mathrm{RH}$ until smoking. They reported highly significant between-consumer variation in the smoke yields measured. They smoked these smaller diameter products using the ISO holder at a butt length of $23 \mathrm{~mm}$. Using a popular brand of tobacco and paper on sale in the United Kingdom, the mean weight of tobacco used was $0.505 \mathrm{~g}$ (range $0.238 \mathrm{~g}$ to $0.818 \mathrm{~g}$ ); the average yield of NFDPM was $15.7 \mathrm{mg}$ (range 9.9 to 21.0); the average yield of nicotine was $1.3 \mathrm{mg}$ (range 0.9 to 1.8 ). The authors point out that, at this diameter, double wrapping of the paper is likely leading to reduced porosity.

It is hoped that the results presented in this paper, together with those previously reported, may have a bearing on a future international standard method for the analysis of fine-cut tobacco smoking articles. This study has once again demonstrated the different consu-mer making practices in use within a single country and even more between countries. Thus a method must be developed that will provide data to reflect the range of parameters used by the consumer. 


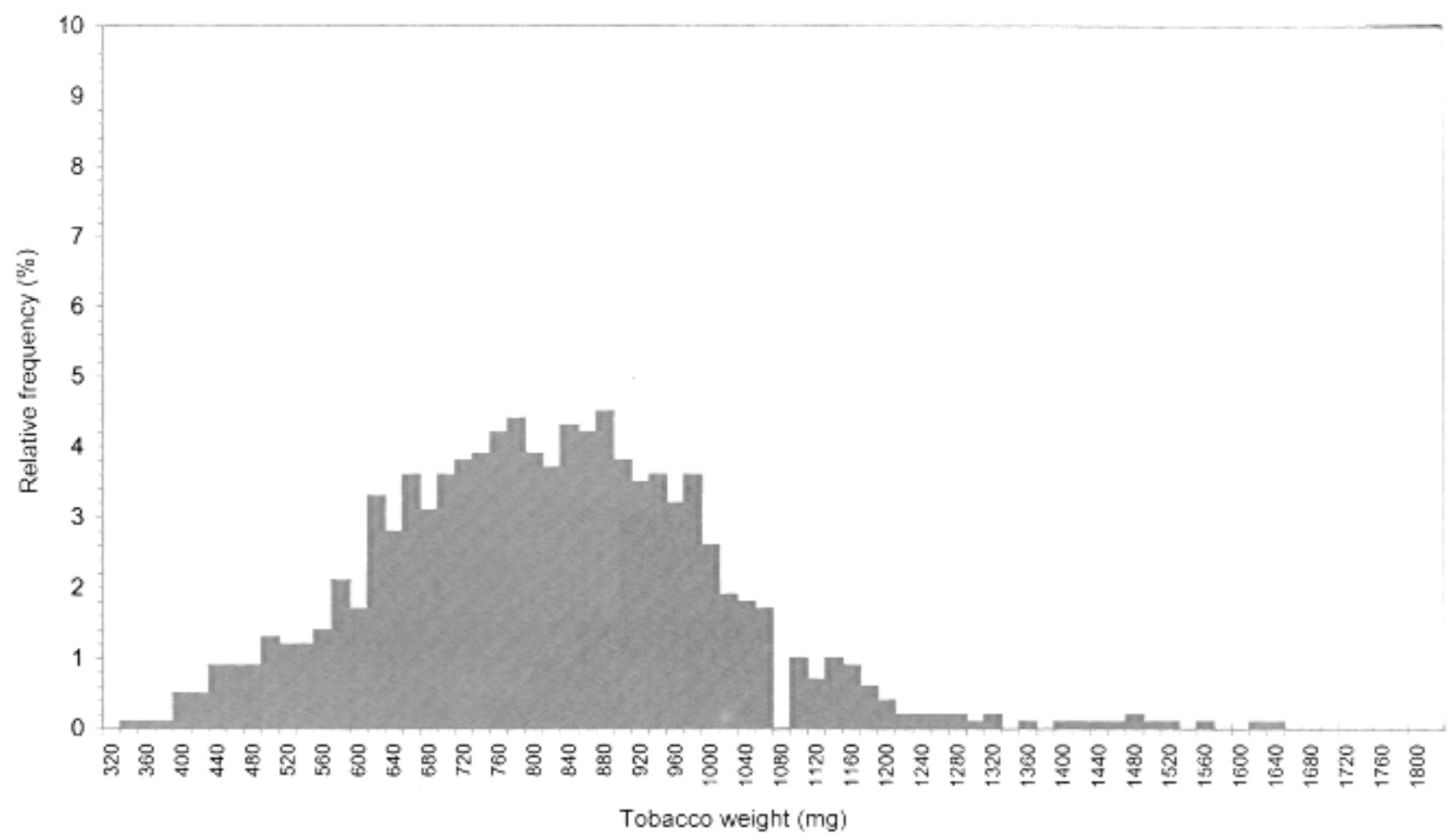

Figure 1a.

Distribution of weight of consumer-made fine-cut smoking articles ( $\mathrm{mg}$ ) (individual fine-cut smoking article level).

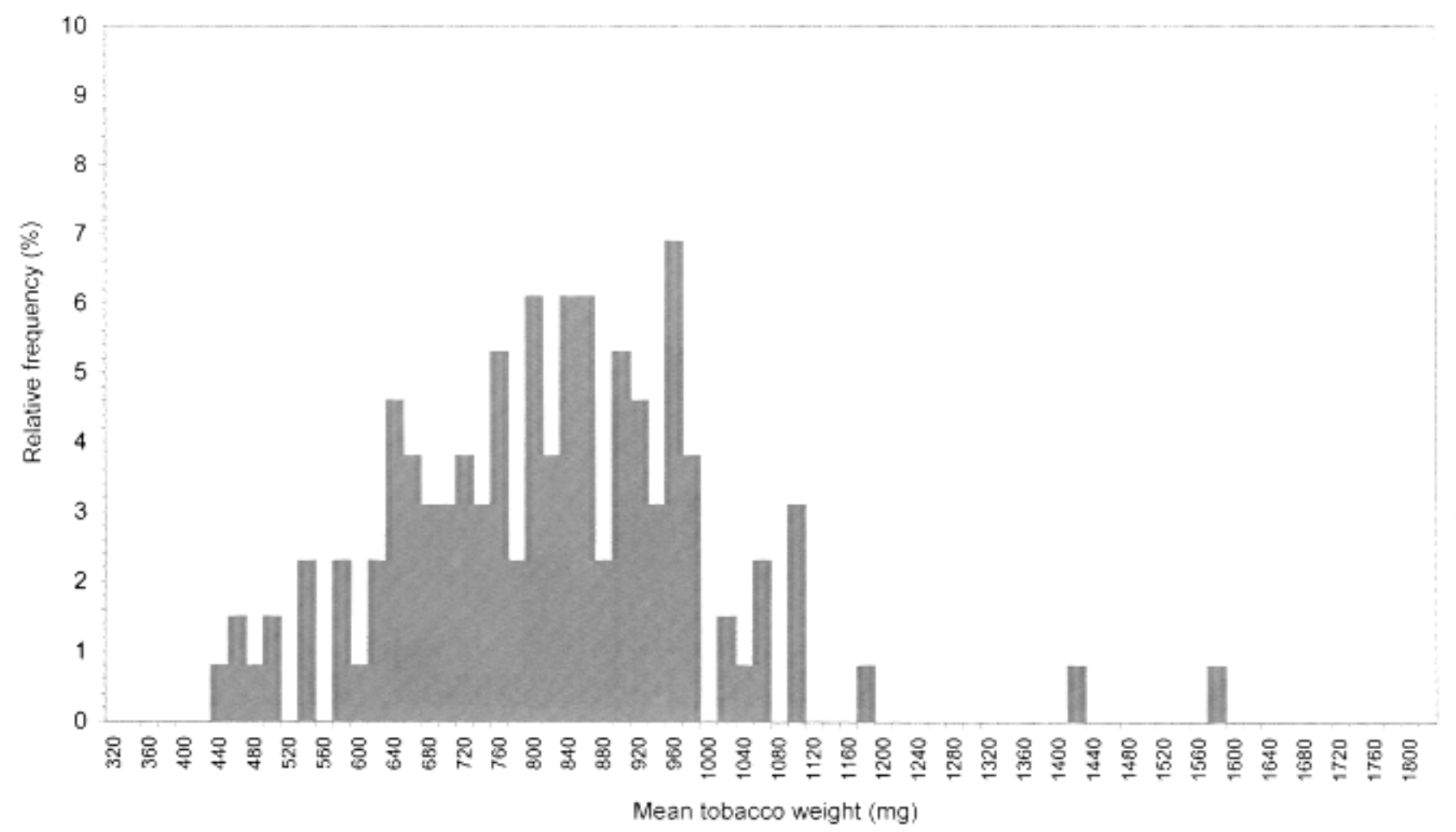

Figure 1b.

Distribution of mean weight of consumer-made fine-cut smoking articles ( $\mathrm{mg}$ ) (respondent level). 


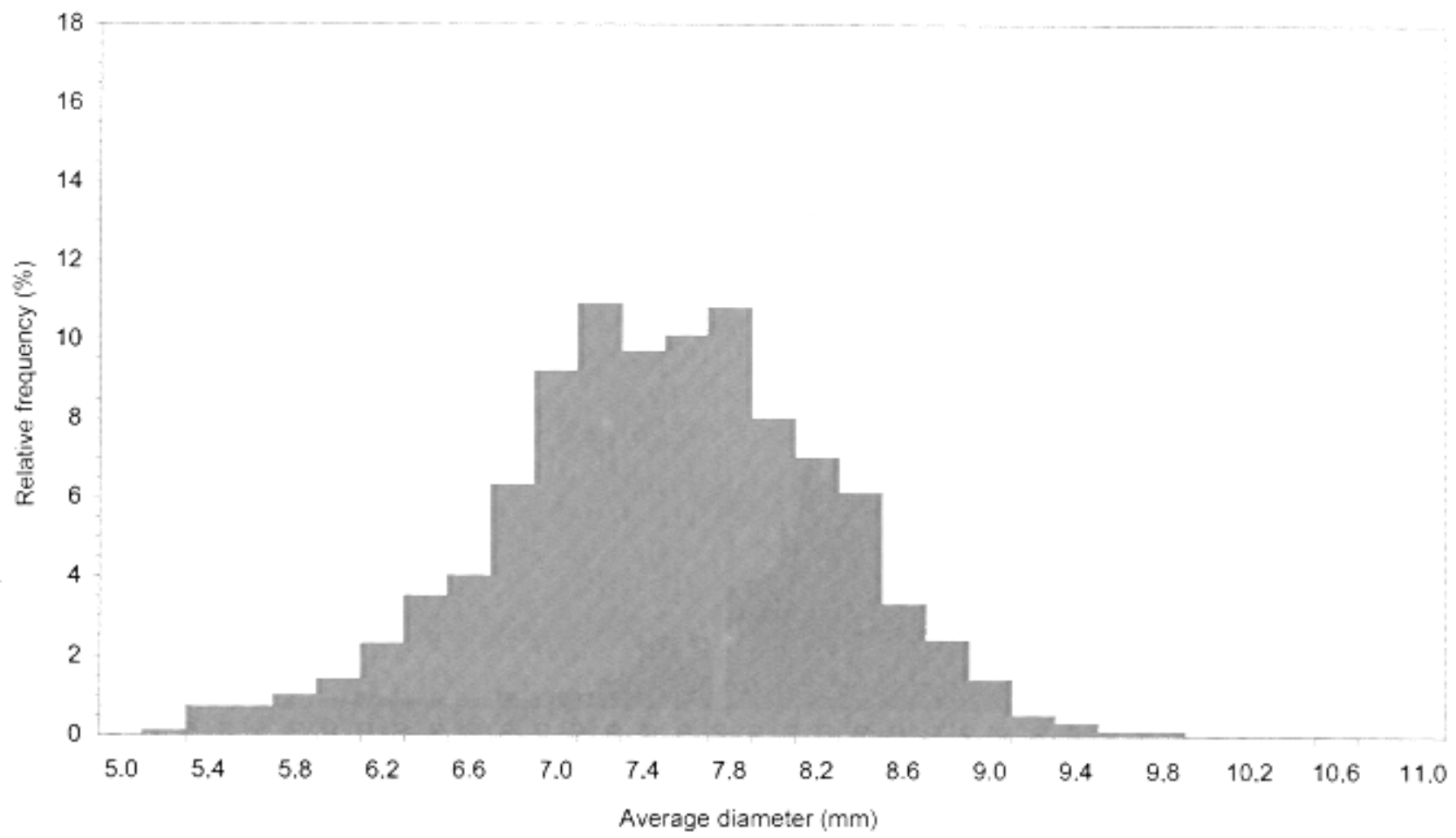

Figure 2a.

Distribution of average diameter $(\mathrm{mm})$ of consumer-made fine-cut smoking artikles (individual fine-cut smoking article level).

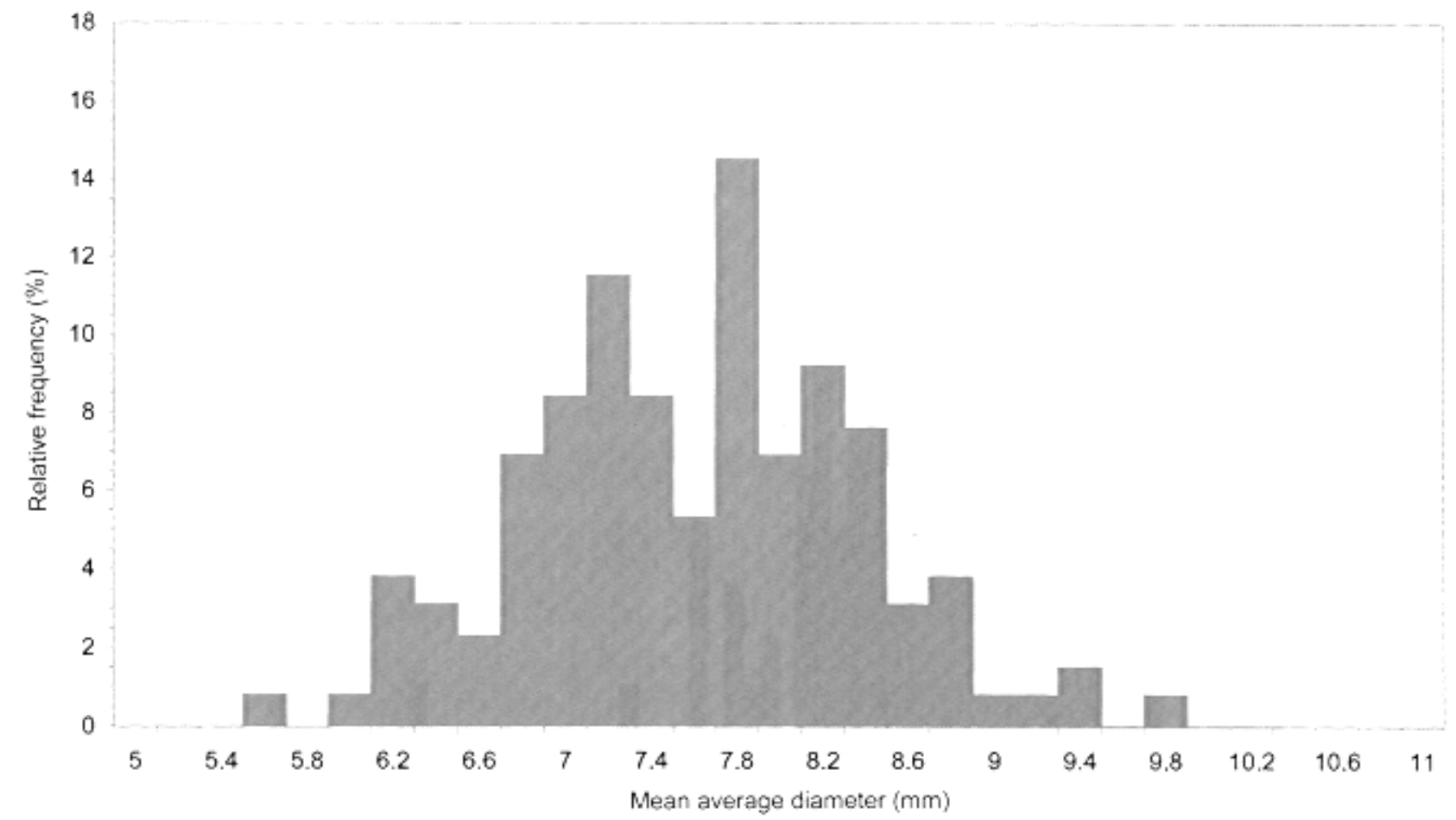

Figure 2b.

Distribution of mean average diameter $(\mathrm{mm})$ of consumer-made fine-cut smoking articles (respondent level). 


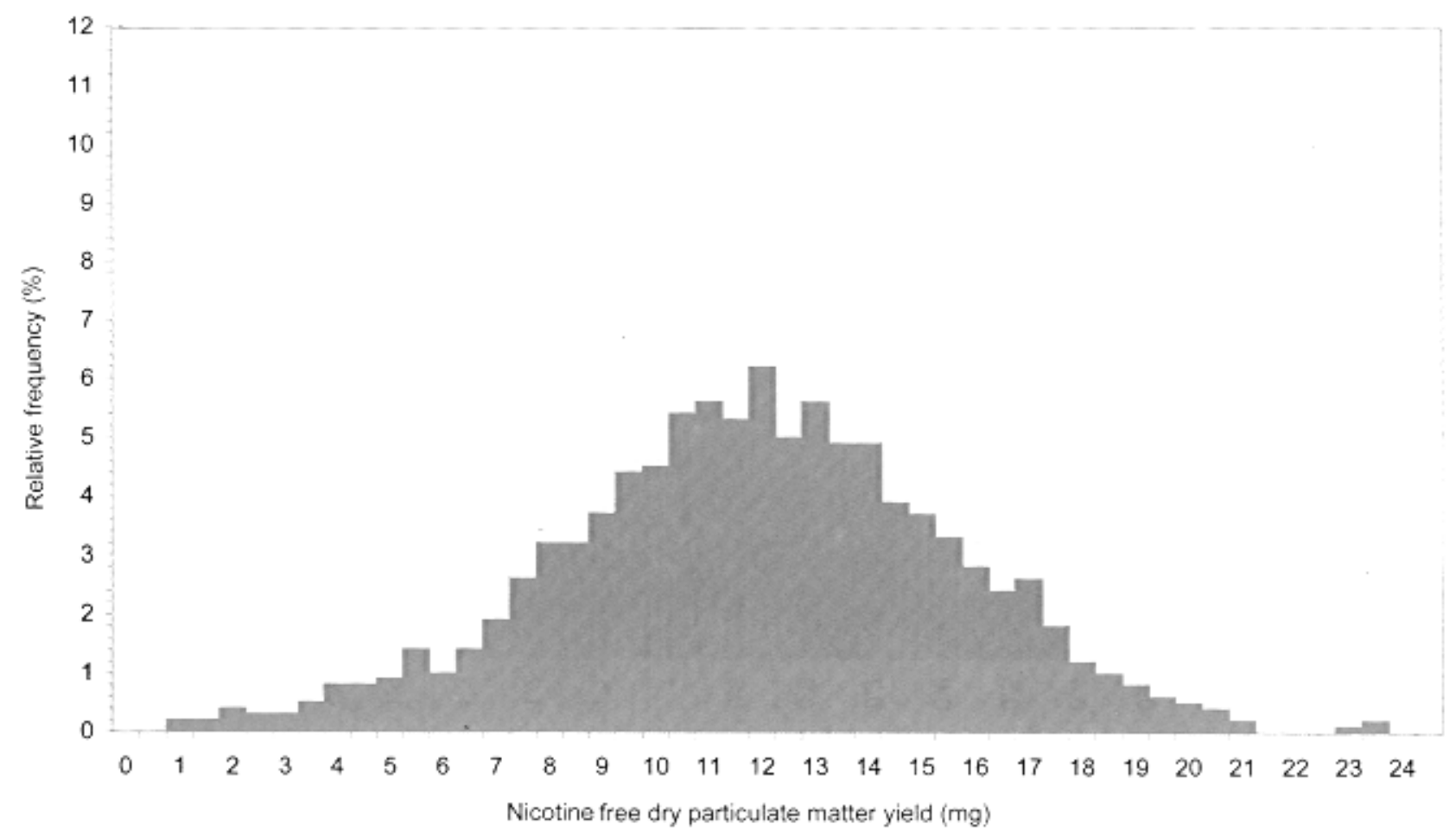

Figure 3a.

Distribution of nicotine-free dry particulate matter yield (mg) (individual fine-cut smoking article level).

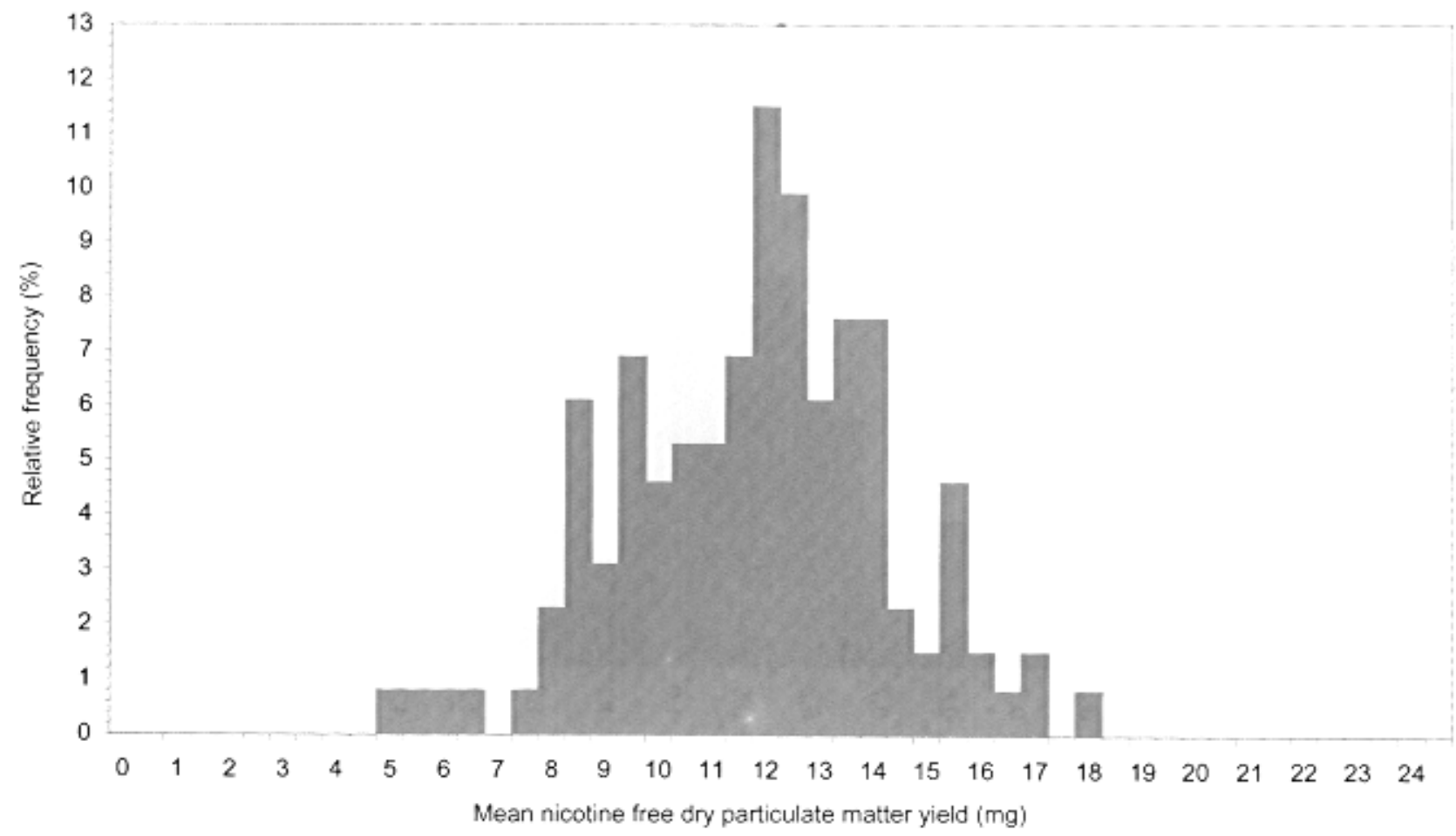

Figure 3b.

Distribution of mean nicotine-free dry particulate matter yield $(\mathbf{m g})$ (respondent level). 


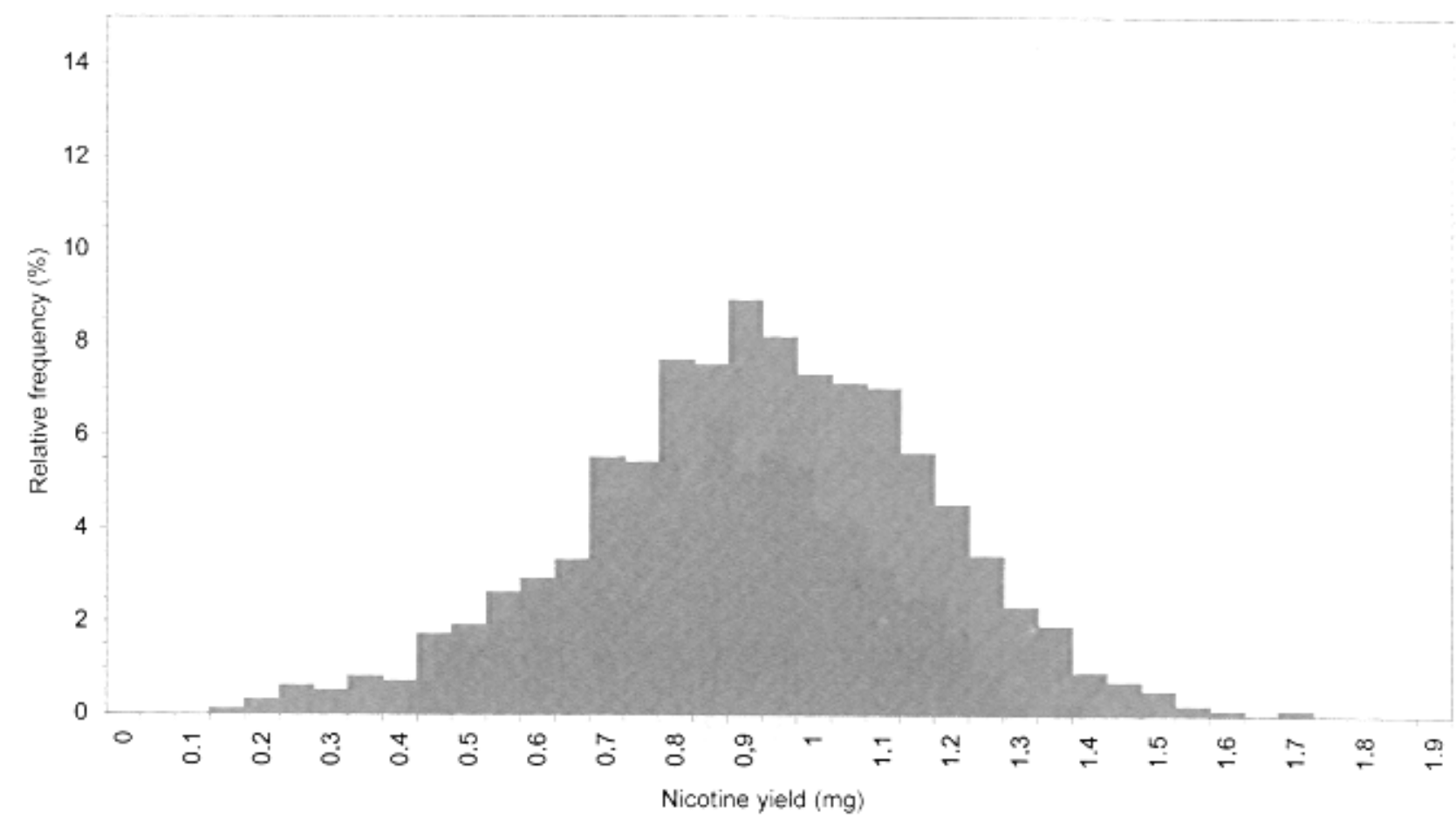

Figure 4a.

Distribution of nicotine yield of consumer-made fine-cut smoking articles (mg) (individual fine-cut smoking article level).

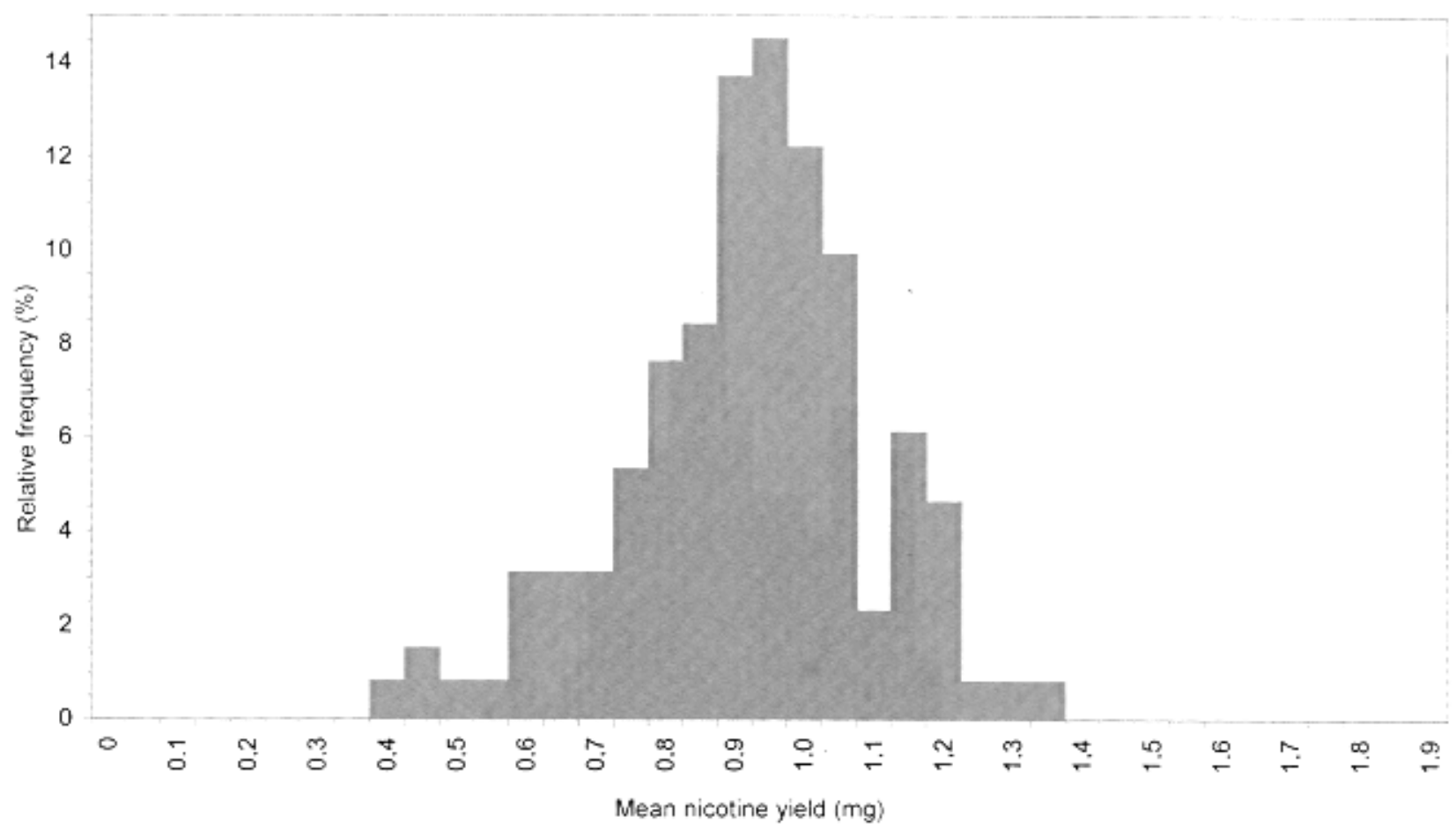

Figure 4b.

Distribution of mean nicotine yield of consumer-made fine-cut smoking articles $(\mathrm{mg})$ (respondent level). 


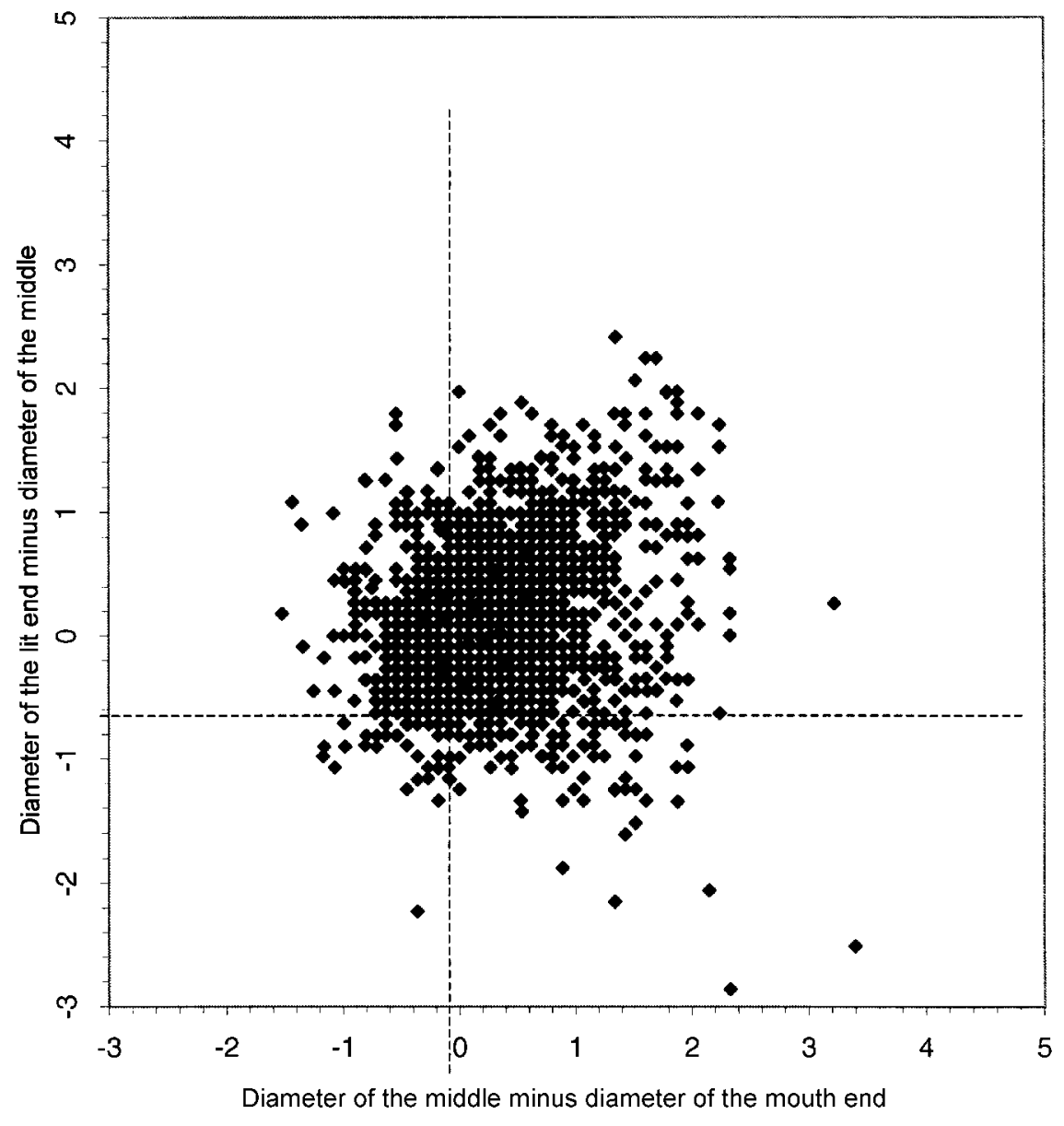

Figure 5.

Distribution of shape of consumer-made fine-cut smoking articles in Germany ( $\mathrm{n}=\mathbf{2 5 7 5}$ ).

\section{REFERENCES}

1. Dymond, H.F: Making habits of roll-your-own smokers in the Netherlands and tar and nicotine yields from the resultant products; Tob. Sci. 40 (1996) 87-91.
2. ISO DIS 6488-2: Tobacco - Determination of water content of tobacco - Karl Fischer method; International Organisation for Standardisation, Geneva, Switzerland, 1995. 


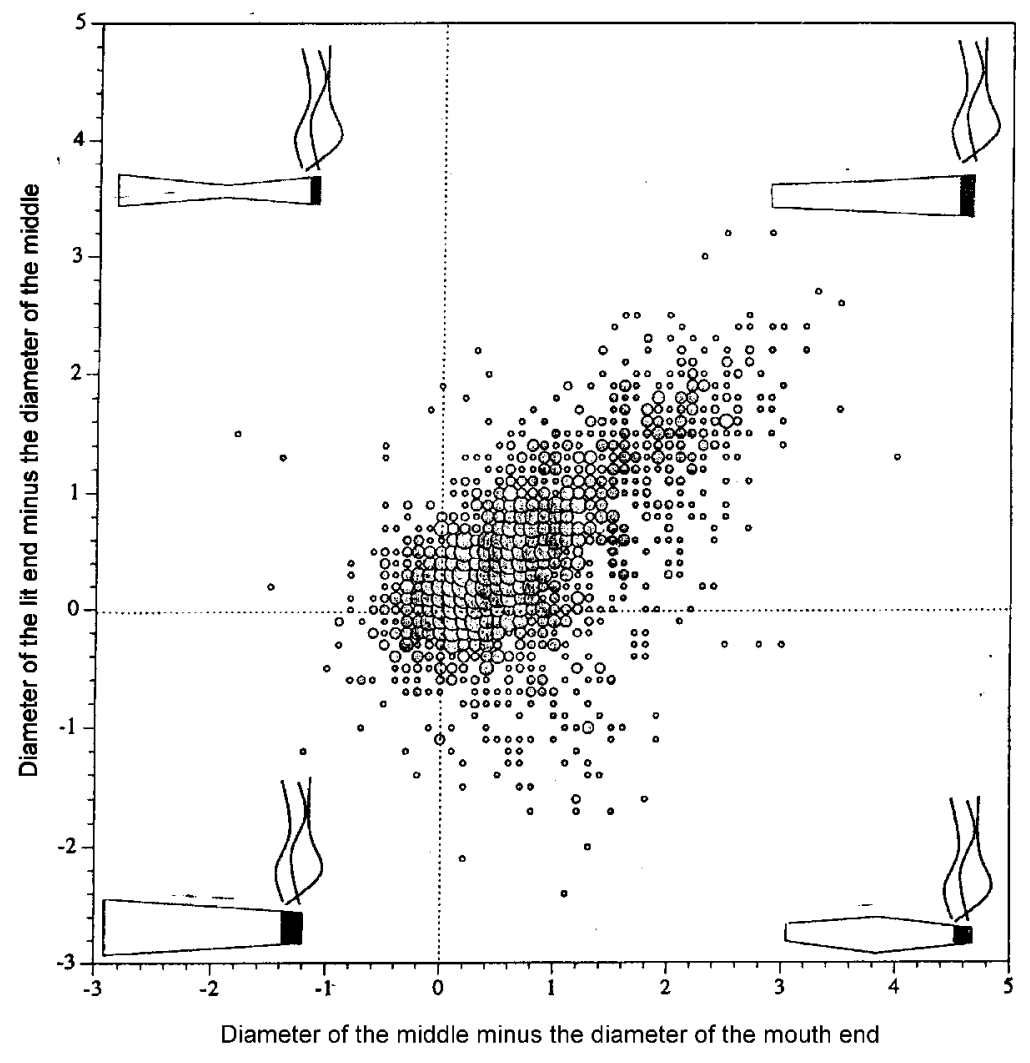

Figure 6.

Distribution of shape of consumer-made fine-cut smoking articles in the Netherlands.

3. ISO 3308: Routine analytical cigarette-smoking machine - definitions and standard conditions; International Organisation for Standardisation, Geneva, Switzerland, 1991.

4. ISO 4387: Cigarettes - Determination of total and nicotine-free dry particulate matter using a routine analytical smoking machine; International Organisation for Standardisation, Geneva, Switzerland, 1991.

5. Darrall, K.G. and Figgins J.A: Roll-your-own smoke yields: theoretical and practical aspects; Tob. Control 7 (1998) 168-175.

Address for correspondence:

Harry F. Dymond,

45, Monarch Way, West End,

Southampton, SO30 3JQ.

United Kingdom. 